\title{
The Effect of Capital Structure on Company Value with Roe as an Intervening Variable in the Banking Sector Listed in BEI 2015-2017
}

\author{
Devy Dwi Puspitasari \\ Narotama University Indonesia \\ devydpuspitasari@gmail.com
}

\begin{abstract}
Company value is the investor's perception of the level of success of the company that is often associated with stock prices. This study aims to examine the effect of capital structure and ROE as an intervening variable on the corporate value of the banking sector listed on the Stock Exchange in 2015-2017.It used quantitative research with an approach that uses numerical data in statistical analysis. With a sample of 10 registered banks and provide financial reports to the Indonesia Stock Exchange (IDX) in the period 2015-2017. In this study using secondary data and with Partial Least Square (PLS) analysis techniques. Research shows that capital structure variables and ROE do not have a significant effect on firm value. While the capital structure has a positive and significant effect on ROE.
\end{abstract}

Keywords: Capital structure, ROE, Company Value

\section{INTRODUCTION}

The development of industrial activities in Indonesia has recently developed very rapidly, including the banking industry. The banking sector has a strategic position and an important role in a country, namely as the achievement of financial system stability, supporting the smooth payment system, and implementing monetary policy. High corporate value is the desire of the owners of the company, because with high value shows the prosperity of shareholders is also high. PBV (Price Book Value) is a ratio that describes how much the market values the book value of shares of a company [1].

One important factor that plays a role in influencing company value is the capital structure which is a balance or comparison between long-term debt with own capital [2]. The capital structure indicator in this study is Debt to Equity Ratio (DER). Whereas for shareholders who invest their capital in the bank, they expect to earn income in the form of dividends or benefit from the increase in share prices. All these activities lead to the goal of obtaining profitability that will be used by banks to finance all operational activities, as well as expansion in activities in future. The ability of the bank itself can be measured by the bank's profitability performance, one of which is by using the Return on Equity (ROE) ratio. ROE is a ratio that measures the ability of bank management to manage existing capital to get net income [3]

\section{LITERATURE REVIEW}

\subsection{Capital Structure (X)}

According to [4], capital structure is a mix or combination of debt, preferred stock, ordinary shares that the company wants in its capital structure. Optimal capital structure is a combination of equity that maximizes the company's stock price. Whereas if there is a problem in the company's capital structure, therefore the problem is a very important and risky problem for the future development of each company, because the company's financial position is always determined by the good and bad capital structure. This research re-examines the role of capital structure on ROE and firm value by using Debt to Equity Ratio which is the ratio of total debt owned by the company to the equity (equity) owned by the company [5] The greater the DER value, the higher the debt the company has compared to its own capital. Hypothesis 1: Capital Structure Does Not Significantly Influence Company Values

Hypothesis 2: Capital Structure Does Not Significantly Affect Company Values with ROE as an intervening variable. 


\section{$2.2 \operatorname{ROE}(\mathrm{Z})$}

Profitability in this study is proxied using Return on Equity (ROE). According to [6] Return on equity (ROE) is the ratio of net income after tax to own capital used to measure the level of return on investment from shareholders. The higher the value of ROE, it can be ascertained that the company's performance will be better, meaning that the position of the company owner is getting stronger and vice versa [7]. This study examines the effect of ROE on firm value and the effect of capital structure on firm value with ROE as intervening varible.

Hypothesis 1: ROE Influences Significance on firm value

Hypothesis 2: Capital Structure Does Not Significantly Affect Company Values with ROE as an intervening variable.

\subsection{Company Value}

Company value is the price that the prospective buyer is willing to pay if the company is sold, the higher the value of a company, the greater the prosperity that will be received by shareholders [8]. This study reexamined the effect of capital structure and ROE on firm value measured using Price to Book Value $(\mathrm{PBV})$ is a ratio that indicates whether the traded stock price is overvalued or undervalued against the stock book value [9]

\section{CONCEPTUAL FRAMEWORK}

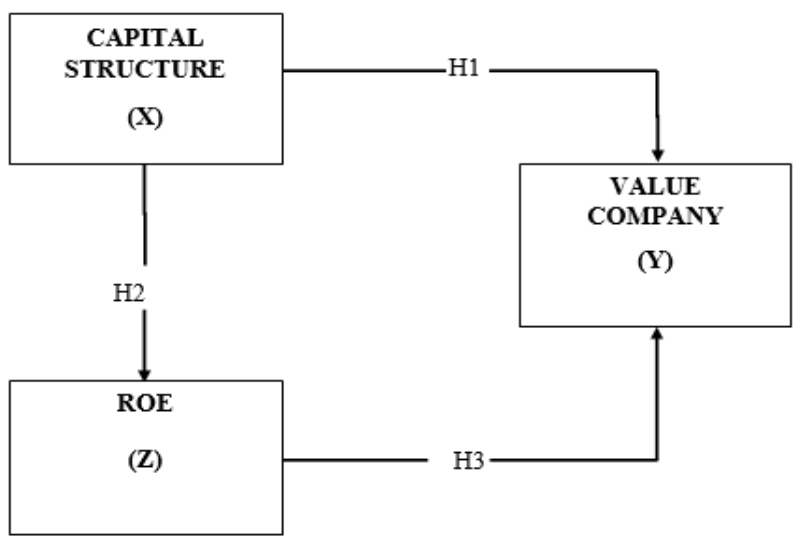

Figure 1 : Research Framwork

Source: Data processed by the author

\subsection{Hypotesis}

\section{Capital Structure and its effect on Corporate Value and ROE as Intervening Variables.}

The trade-off theory explains that if the position of the capital structure is below the optimal point, any additional debt will increase the value of the company. And vice versa, every time the position of the capital structure is above the optimal point, any additional debt will reduce the value of the company. The results showed that the capital structure had a negative and not significant effect on the value of the company in accordance with previous research from Julia Putri with her research entitled "The Influence of Capital Structure on Corporate Values in Manufacturing Companies Go Public (Case Study of Food and Beverage Sector)".

H0: Capital Structure Does Not Have a Positive and Significant Effect on Firm Value with ROE as an intervening variable.

H1: The Capital Structure Has No Negative and Significant Impact on Company Values. 


\section{Capital Structure and its effect on the ROE of the Company.}

Basically the company is considered good if it has and shows a good capital structure too, because good and bad capital structure will have an impact on the company's financial position which indirectly will ultimately affect the profitability of the company. The capital structure only has mixed funds consisting of debt and capital. When the use of corporate debt increases, profitability will decrease, and vice versa if the greater the level of profitability the company has, then it will show good management performance in managing the company.

The results of the study show that the capital structure has a positive and significant effect on the value of the company in accordance with previous research from Md. Bokhtiar Hasan, A. F. M. Mainul Ahsan, Md. Afzalur Rahaman \& Md. Nurul Alam with his research entitled "Influenceof Capital Structure on Firm Performance: Evidence From Bangladesh".

H2: Capital Structure Has Positive And Significant Effects on Company ROE.

\section{ROE and its effect on Company Value}

The higher the value of ROE, it can be ascertained that the company's performance will be better, meaning that the position of the company owner is getting stronger and vice versa (Kasmir, 2008). The above situation identifies that investors will not only see the company's ability to obtain maximum profits, but also see the amount of debt used by the company in carrying out its operational activities. The use of large and higher debt in a company will be able to influence the level of profits obtained by investors, because with greater use of debt, the greater the interest expense that will be borne by a company will reduce the level of profit the company can obtain and will have an impact on the value of the company (Bringham, 2001).

The results showed that ROE had a positive but not significant effect on the value of the company in accordance with previous research from Nia Puput Febriani with his research entitled "The Influence of Capital Structure, Profitability and Firm Size on Firm Value in Basic and Chemical Industry Companies Listed on the Stock Exchange Indonesian Securities (Bei) Period 2013-2015 "

H3: ROE has a Positive and Significant Effect on Firm Value.

\section{RESEARCH METHOD}

The type of research used by the authors in this study is categorized as associative research. According to [10]Associative research is research that aims to determine the effect or also the relationship between two or more variables, namely the independent variable that influences $(\mathrm{X})$ on the dependent variable which is influenced by (Y). The approach used in this study is a quantitative approach. A quantitative approach is an approach that uses numerical data in statistical analysis. The sample used in this study is 10 banking sector companies that have been listed on the Indonesia Stock Exchange (IDX) for the period 2015-2017 and fulfill the criteria used for population selection with the analysis method using Partial Least Square (PLS) using SmartPLS3 software.

The criteria used for population selection in this study are:

1) There is a Financial Report on the IDX in the last 3 studies, namely 2015, 2016 and 2017.

2) Never split shares in research.

3) Suspend has never been carried out by related parties.

4) Never suffered a loss during the study year.

5) Having a relatively stable profit.

\section{RESULTS AND DISCUSSION}

\subsection{Research Result}

The sample used in this study is 10 banking sector companies listed on the Indonesia Stock Exchange in 2015-2017 and have met the specified criteria. The list of banks is among others 
Table 1

List of Companies in the Banking Sector

\begin{tabular}{|c|c|c|c|}
\hline NO & CODE & JOIN YEAR & BANK NAME \\
\hline 1 & BBCA & 31 May 2000 & PT.Bank Asia Central Tbk \\
\hline 2 & BBNI & 25 November 1996 & PT. Bank Negara Indonesia (Persero) Tbk \\
\hline 3 & BBTN & 17 December 2009 & PT. Bank Tabungan Negara (Persero) Tbk \\
\hline 4 & BBKP & 10 July 2006 & PT. Bank Bukopin Tbk \\
\hline 5 & BDMN & 6 December 1989 & PT. Bank Danamon Indonesia \\
\hline 6 & BMRI & 14 Juli 2003 & PT. Bank Mandiri (Persero) Tbk \\
\hline 7 & BNGA & 29 November 1989 & PT. Commerce Intemational Merchant Bankers \\
\hline 8 & MAYA & 29 August 1997 & Bank Mayapada Internasional Tbk \\
\hline 9 & MEGA & 17 Apri1 2000 & PT. Bank Mega Tbk \\
\hline 10 & BNLI & 15 January 1990 & PT. Bank Permata Tbk \\
\hline
\end{tabular}

Source : www.idx.co.id (Data Processed by Author)

\subsection{Discussion Of Research Results}

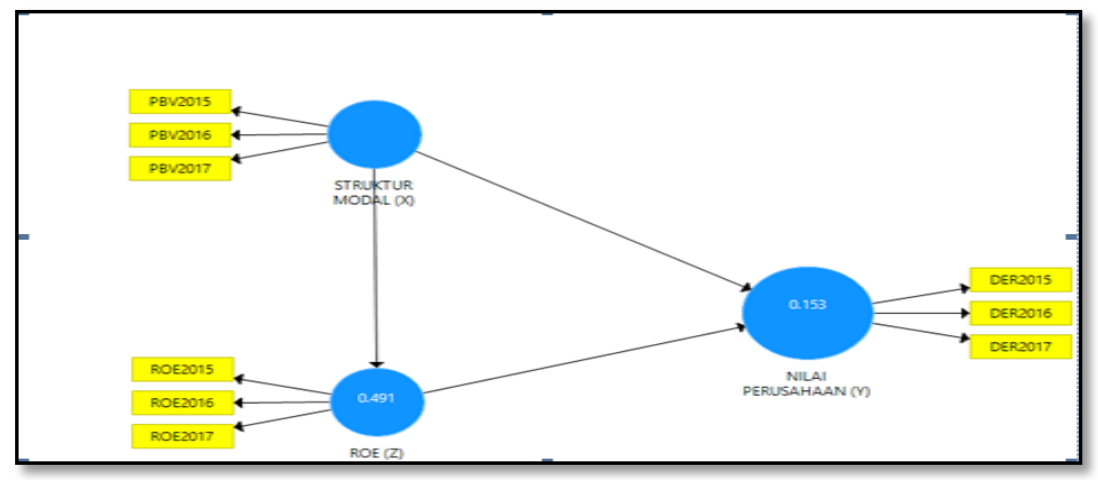

Figure 2 : Model Struktural

Source: Researcher, Output, SmartPLS 3

The picture above shows that the construct of Capital Structure $(\mathrm{X})$ is measured by 3 indicators, namely DER2015, DER2016 and DER2017. Likewise, the construct of ROE (Z) is measured by 3 indicators, namely ROE2015, ROE2016, ROE2017, and the construct of Corporate Value (Y) also measured by 3 indicators namely PBV2015, PBV2016, and PBV2017. The direction of the arrow between indicators with latent constructs is towards indicators that show that research uses reflective indicators that are relatively appropriate for measuring perceptions. The relationship to be examined (hypothesis) is symbolized by an arrow between constructs.

\section{Validity test (Outer Model)}

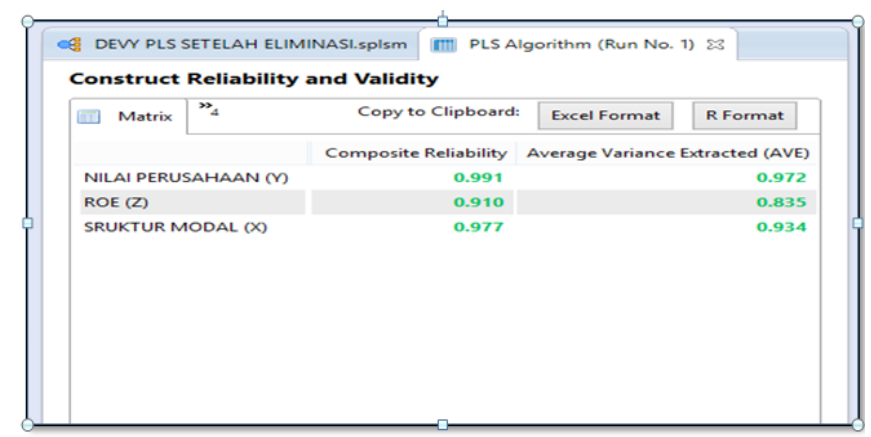

Figure 3 : Validity test (Outer Model)

Source: Researcher, Output, SmartPLS 3 
Based on the composite reliability value presented in Figure 3, it shows that all three latent variables have composite reliability values above 0.9 . This means that predetermined indicators have been able to measure each latent variable (construct) properly or it can be said that the three measurement models are reliable. The better the value of Convergent validity is indicated by the higher correlation between the indicators that make up a construct.

The AVE value shown in Figure 3 shows that the three latent variables have AVE values above the minimum criteria, which is 0.8 , so the size of the convergent validity is good or it can be said that it meets the convergent validity criteria. The next criterion is discriminant validity. In discriminant validity test can be seen from the value of cross loadings of each indicator that will be examined. The results of discriminant validity testing through SmartPLS in this study can be explained in the picture below:

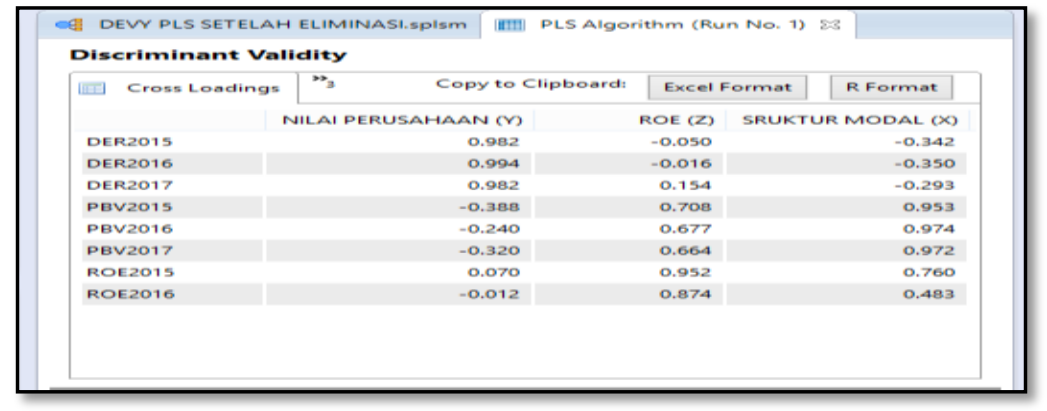

Figure 4 : Cross Loading

Source: Researcher, Output, SmartPLS 3

In Figure 4 above, it can be explained further about the results of cross loadings from the variable capital structure, ROE and the value of the company with the indicator which is higher in value than the correlation of indicators with other variables. Thus it is known that all indicators in each variable used in this study meet the requirements of discriminant validity.

\section{Reliability Test}

Reliability test can be done in two ways, namely to see the value of composite reliability contained in the indicator used to measure the construct or by using cronbach's alpha. The results of Composite Reliability and cronbach's alpha will show satisfactory values if they are> 0.7 . The following is table 3 of the Composite Reliability and cronbach's alpha values in this study:

\section{Tabel 3}

Cronbach's Alpha dan Composite Reliability

\begin{tabular}{|c|c|c|}
\hline Variable & Cronbachs Alpha & Composite Reliability \\
\hline Value Company (Y) & 0,986 & 0,991 \\
\hline Roe (Z) & 0,811 & 0.910 \\
\hline Capital Structure (X) & 0,965 & 0,977 \\
\hline
\end{tabular}

Source: Researcher, Output, SmartPLS 3

Based on table 3 the results of the output value of Cronbach's alpha and composite reliability from the capital structure, ROE and company value show a value of $\geq 0.70$, which means that all the above variables have discriminant validity criteria. The highest Cronbach's Alpha and composite reliability values are 0.986 and 0.991 , which is the indicator of firm value.

\section{Testing of Structural Models (Inner Model)}

$\mathrm{R}$ Square $\left(\mathrm{R}^{2}\right)$ testing is a way to measure the level of Goodness of Fit (GOF) of a structural model. $\mathrm{R}$ Square value $\left(R^{2}\right)$ is used to assess how much influence the independent latent variable has on the dependent latent variable. According to Chin (1998), the value of $\mathrm{R}$ square is 0.67 (strong), 0.33 (moderate) and 0.19 (weak). below is a table 5 that addresses the value of $\mathrm{R}$ Square in this study, namely: 
Table 4

R Square $\left(\mathbf{R}^{2}\right)$

\begin{tabular}{|c|c|c|}
\hline Variable & Rsquare $\left(\mathbf{R}^{2}\right)$ & Information \\
\hline Value Company (Y) & 0,261 & Moderat \\
\hline Roe (Z) & 0,501 & Moderat \\
\hline Average & 0,381 & Moderat \\
\hline
\end{tabular}

Source: Researcher, Output, SmartPLS 3

Judging from the 4.8 tavel above, it gives a value of 0.261 for the construct of Corporate Value (Y) which means that the capital structure (X) is only able to give a value to the firm value (Y) of $26.1 \%$. Whereas for ROE as an intervening variable is able to give a value of 0.501 , which means capital structure (X) and ROE (Z) give a value of $50.1 \%$ on the value of the company $(\mathrm{Y})$. Based on the R-square value in table 4.8 above, it can also be seen that the average value of the 2 variables is $38.1 \%$ or 0.381 which can be said that the model in this study is categorized as a Moderate Model. The formula for counting GoF is:

\section{Gof $=\sqrt{\text { communality } x \mathrm{R}^{2}}$}

Goodness of fit can also be assessed by knowing the value of Q-square, because the higher the Qsquare, the better the model can be said. The results of the calculation of the Q-square value of this study are as follows:

$$
\begin{aligned}
\mathrm{Q}^{2} \quad=1- & \left(1-\mathrm{R} 1^{2}\right)\left(1-\mathrm{R} 2^{2}\right) \\
& =1-(1-0,261)(1-0,501) \\
& =1-(0,739)(0,499) \\
& =1-0,369 \\
& =0,631
\end{aligned}
$$

From the results of the predictive Q - square relevance above obtained a value of 0.982 . This can be interpreted the amount of diversity obtained from the research data that can be explained by the research model is $63.1 \%$ and the remaining $36.9 \%$ is explained by other factors that are outside the research model. The results can be drawn that this research model has good goodness of fit.

\section{Hypothesis testing}

Testing the hypothesis in this study using the bootstrapping test and for more details will be explained in the path coeficient table below:

Table 6

Path Coeficient

\begin{tabular}{|c|c|c|c|c|c|}
\hline Path Coefficient & $\begin{array}{c}\text { Original } \\
\text { sample } \\
(\mathbf{O})\end{array}$ & $\begin{array}{c}\text { Sample } \\
\text { Average } \\
(\mathbf{M})\end{array}$ & $\begin{array}{c}\text { Standard } \\
\text { Deviation } \\
\text { (STDEV) }\end{array}$ & $\begin{array}{c}\text { T Statistic } \\
(|\mathbf{O}, \mathbf{S T D E V}|)\end{array}$ & P Value \\
\hline $\begin{array}{c}\text { Capital Structure (X) } \rightarrow \\
\text { Value Company (Y) }\end{array}$ & $-0,721$ & $-0,722$ & 0,629 & 1,146 & $\mathbf{0 , 1 2 6}$ \\
\hline $\begin{array}{c}\text { Capital Structure (X) } \rightarrow \\
\text { ROE (Z) }\end{array}$ & 0,708 & 0,704 & 0,0205 & 3,460 & 0,000 \\
\hline $\begin{array}{c}\text { ROE (Z) } \rightarrow \text { Value } \\
\text { Company (Y) }\end{array}$ & 0,552 & 0,583 & 0,634 & 0,870 & $\mathbf{0 , 1 9 2}$ \\
\hline
\end{tabular}

Source: Researcher, Output, SmartPLS 3

H1: The first hypothesis is rejected. The table above shows that the capital structure does not have a significant effect on company value because this t-statistic value is $1.146<1.661$ and the p-value is $0.126>0.05$.

$\mathrm{H} 2$ : The second hypothesis is accepted. The table above shows that the capital structure has a positive and significant effect on ROE because the t-statistic value is 3.460>1.661 and the p-value is $0,000<0.05$. 
H3: The table above shows that ROE does not affect the company's value because this value of t-statistic is $0.870<1.661$ but the p-value is $0.192>0.05$.

\section{CONCLUSION AND RECOMMENDATION}

\subsection{Conclusion}

This study aims to analyze the presence or absence of influence between the capital structure variables, ROE and firm value on 10 banking sector companies listed on the Stock Exchange in 2015 - 2015, and already meet the required sample criteria. The technique used in analyzing the relationships between these variables, researchers used the Partial Least Square (PLS) equation. Based on the analysis and discussion in the previous section, the conclusions can be taken as follows: H1: There is a non-significant negative influence on the variable "Capital Structure of the Value of Banking Sector Companies Listed on the Stock Exchange in 2015 - 2017". H2: The existence of Positive and Significant Influences on the Variable "Capital Structure Against the ROE of Banking Sector Companies Listed on the Stock Exchange in 2015 - 2017". H3: The existence of Positive Influence but Not Significant in the Variable "ROE Against the Value of Banking Sector Companies Listed on the Stock Exchange in 2015 - 2017".

\subsection{Recommendation}

Based on the research that has been done above, the researcher will give some suggestions that are expected to be useful for readers and especially other researchers who will examine the same thing. Suggestions that researchers can provide include:

1) It is expected that in the future researches can take more and more specific variables and with more names of banks listed therein accompanied by the year of the latest research.

2) The author hopes that the banking sector companies can significantly provide the company's financial report data to the Indonesia Stock Exchange to help further research obtain more detailed and complete data.

3) For the 10 banking sector companies listed on the Indonesia Stock Exchange in 2015 - 2017. In accordance with the results of the study which states that the capital structure does not significantly affect the company's value, it is expected that 10 companies can increase their corporate value by: avoiding the DER value relatively high, expanding the area or branch of the bank, managing the allocation of funds appropriately, increasing company profits etc.

\section{REFERENCES}

[1] Darmadji \& Fakhruddin, Pasar Modal di Indonesia, Tiga. Jakarta: Salemba Empat, 2011.

[2] B. Riyanto, Dasar - dasar Pembelanjaan Perusahaan, Edisi 4. Yogyakarta: BBFE, 2001.

[3] Kasmir, Analisis Laporan Keuangan (Cetakan Kelima). Jakarta: PT. Raja Grafindo persada, 2012.

[4] Brigham dan Houston, Dasar-dasar Manajemen Keuangan Buku 1, Dua. Jakarta: Salemba Empat, 2010.

[5] Syamsuddin, Manajemen Keuangan Perusahaan. Jakarta: PT. Raja Grafindo persada, 2009.

[6] J. F. dan T. E. C. Weston, Manajemen Keuangan. Jakarta: Binarupa Aksara, 2010.

[7] Kasmir, Analisis Laporan Keuangan. Jakarta: Rajawali Pers, 2008.

[8] S. dan E. P. Husnan, Dasar-Dasar Manajemen Keuangan, Kelima. Yogyakarta: UPP STIM YKPN, 2006.

[9] F. dan H. Fakhruddin, Manajemen Investasi Portofolio. Jakarta: Salemba Empat, 2001.

[10] A. Sugiono, Manajemen Keuangan Untuk Praktisi Keuangan. Jakarta: Grasindo, 2009. 